\title{
Um novo meio de prova no Código de Processo Civil Português de 2013: a verificação não judicial qualificada'
}

A new mean of evidence in Portuguese Civil Procedure Code 2013: observation by a technicien

Maria José Capelo'

${ }^{1}$ Universidade de Coimbra - Portugal

\section{Resumo}

Este estudo analisa o novo meio de prova - verificações não judiciais qualificadas - consagrado no Código de Processo Civil Português de 2013, num esforço de clarificar e delimitar o seu âmbito de aplicação, distinguindo-o da inspeção judicial e da perícia.

Palavras-chave: Meios de Prova. Verificação Não Judicial Qualificada; Técnico. Oficial Público. Inspeção Judicial. Perícia.

\begin{abstract}
This study refers to a new mean of evidence - "observation by a technicien" - introduced in (portuguese) Civil Procedure Code 2013, in order to delimit its field of application and distinguish it from others means of evidence such as the judicial inspection and the expertise.
\end{abstract}

Keywords: Evidence. Observation. Technicien. Public Official. Inspection. Expertise.

\section{Introdução}

No Código de Processo Civil², aprovado pela Lei n.o 41/2013, de 26 de Junho, no Capítulo V do Título V, reservado à Inspeção Judicial, inseriu-se uma figura denominada "Verificações não judiciais qualificadas" (artigo 494. do CPC-Código de Processo Civil). Prevê-se o recurso a este expediente probatório, sempre que seja legalmente admissível inspeção judicial, mas o juiz entenda que tal diligência se não justifica face à natureza da matéria. Neste circunstancialismo, o tribunal pode incumbir um técnico ou uma pessoa qualificada de proceder a actos de inspeção (de coisas ou lugares) ou de reconstituição de factos. De tal atividade será lavrado relatório, apreciado à luz do princípio da livre apreciação (salvo se as atestações constarem de documento emanado de autoridade pública).Estaremos perante um meio de prova alternativo à inspeção de coisas e lugares ${ }^{3}$ ou à reconstituição de factos presenciada pelo juiz? Qual a sua função no sistema processual? O papel do técnico será equiparável ao do perito, sujeitando-se, por

1 O presente texto corresponde, com alterações, ao nosso estudo «As verificações não judiciais qualificadas: reforço ou desvirtuamento da prova por inspecção judicial?», publicado na Revista de Legislação e Jurisprudência, Ano $144 .^{\text {.o }}$, № 3992 (Maio-Junho de 2015), pp. 330-340.

2 Doravante designado CPC.

3 As "pessoas" estão excluídas enquanto objeto da atividade de "inspeção" por parte do técnico ou pessoa qualificada. A inadmissibilidade de verificação não judicial qualificada de pessoas justifica-se, quer-nos parecer, pela possibilidade de as "pessoas" se deslocarem a tribunal e pelas garantias de proteção da dignidade ou da intimidade da vida privada que rodeiam a "inspeção" de pessoas. 
conseguinte, às regras que regem a perícia? Qual é o procedimento que rege este novo meio de prova quanto à escolha da "pessoa qualificada", à fixação do objecto e à participação das partes nesta atividade probatória? Será razoável permitir que um técnico/pessoa qualificada assista à reconstituição dos factos em "substituição" do juiz da causa?

Todas estas questões colocam-se, posto que emergiu um novo meio de prova, sem uma estrutura normativa que o sustentasse. A remissão do artigo 494.ํㅜ do CPC para os preceitos que regem a inspeção judicial, revela-se parca de significado e dúbia. As notas caracterizadoras da inspeção judicial tornamna "especial", pelo que dificilmente se concebem razões que justifiquem a "delegação" de atividades (de inspeção) a terceiro.

Na inspeção nada se interpõe entre os sentidos do juiz e as coisas, pessoas ou lugares, sendo um meio privilegiado de formação da convicção ${ }^{4}$. O lustre processualista português José Alberto dos Reis caracteriza-a como "a prova directa, por excelência", explicando que «ao passo que, nos outros meios probatórios, o juiz serve-se de intermediários, na inspecção judicial não há intermediário algum: o magistrado é posto em contacto directo e imediato com o próprio facto a provar» ${ }^{5}$. Logo, a atribuição a terceiro de atividade de "inspeção" parece beliscar o valor de imediação, afectando a utilidade que adviria da "proximidade" do juiz com a fonte da prova. Um Acórdão da Relação de Coimbra ${ }^{6}$, de 14/10/2014, sublinha que «a prova por meio de inspecção ou reconhecimento judicial é frequentemente idónea para convencer o juiz, de modo extraordinariamente simples, da existência ou inexistência de um facto; que o juiz que a realiza está em condições, melhor que ninguém, de determinar o seu alcance probatório».

Em conformidade, quer-nos parecer que o recurso a uma verificação não judicial qualificada, no lugar de uma inspeção judicial, deverá ser residual. O seu âmbito de aplicação carece de ser bem delineado e circunscrito, sob pena de se desvirtuar a inspeção judicial.

De qualquer modo, antes de profetizarmos sobre a bondade deste novo meio de prova, convém dissecar os seus pressupostos e procedimento probatório.

\section{A "natureza da matéria" como fundamento do recurso à verificação não judicial qualificada.}

"Sempre que seja legalmente admissível a inspeção, mas o juiz entenda que não se verifica, face à natureza da matéria..." (artigo 494..$^{\circ}$, n. 1$)$.

Da leitura do preceito e da sua inserção sistemática parece inferir-se que a verificação por um técnico ou pessoal qualificado surge como alternativa a uma inspeção judicial. Na análise desta "alternatividade", temos como ponto de partida a ideia de que estamos perante dois meios de prova distintos, embora com objectos semelhantes. A atividade de inspeção de coisas ou lugares, quando é realizada por alguém que não é juiz, já não é inspeção judicial'.

O que justifica a "dispensa" da inspeção judicial e o decretamento de uma verificação não judicial? O critério avançado pelo legislador é este: a inspeção judicial é conveniente para a apuramento da

4 Cf. Antunes Varela/ M. Bezerra/ Sampaio Nora, Mamual de Processo Civil, Coimbra Editora, 1985 , pp. 603 e 604.

5 Cf. José Alberto dos Reis, Código de Processo Civil anotado, volume IV, Coimbra 1987, p. 306 (itálico do autor). Antunes Varela/M. Bezerra/Sampaio Nora (ob.cit., p. 602)) caracterizam-na como prova real, pois o «instrumento probatório é uma coisa: o imóvel, o móvel, o desvio de água, o ferimento nos animais, etc.».

6 Processo 1622/12.2TBGRD.C1, in www.dgsi.pt.

7 No contexto processual brasileiro, Luiz Rodrigues Wambier/Eduado Talamini (Curso Avançado de Processo Civil, volume 2, 17. ed., São Paulo: Thomson Reuters, 2018, p. 368) referem que «é da essência da inspeção judicial a presença do juiz, na aferição direta e pessoal do objeto inspecionado, fora da sede do juízo», assinalando que «não tem valor de inspeção uma verificação feita por um auxiliar do juiz (oficial de justiça, perito, etc.), ainda que por ordem dele». EduARdo Cambi ( A Prova Civil - Admissibilidade e Relevância, Editora Revista dos Tribunais, 2006, p. 250) critica o parágrafo único da Lei dos Juizados Especiais Cíveis, no qual se permite que uma pessoa da confiança do magistrado inspecione pessoas e coisas, relatando-lhe informalmente o verificado. Sustenta que esta atividade probatória já não é inspeção, pois esta deve dar-se sempre por meio do juiz, estando-se, neste circunstancialismo, perante uma hipótese de prova testemunhal (cf.ob.loc.cit). 
realidade, mas revela-se inadequada atendendo à natureza da matéria. Isto é, a opção pela verificação não judicial fundamenta-se nas características do objecto da perceção (ou da atividade de reconstituição de factos). Anote-se que não se elegeram, como fundamento da "dispensa" de uma inspeção pelo juiz, os atrasos ${ }^{8}$ que possam advir desta missão a cargo do juiz, nomeadamente quando seja necessário que "saia" do tribunal e se desloque a um local. Repare-se, de igual modo, que a preferência pela verificação não judicial, em detrimento de uma inspeção realizada pelo juiz, não assenta nas eventuais dificuldades práticas (inclusive perigosidade) na sua execução". Isto é, tais obstáculos "logísticos" não impedem, em regra, a realização da inspeção judicial. A lei acautela-os quando prevê (como já se previa no Código anterior) a possibilidade de o tribunal ser auxiliado por um técnico na inspeção (artigo 493. ${ }^{\circ}$ do CPC) ${ }^{10}$. Ou seja, sempre que o juiz preveja dificuldades práticas, tem ao seu alcance a prerrogativa de nomear um técnico para o auxiliar. A sua escolha pode assentar na competência deste para suprir os riscos de determinada atividade percetiva (por exemplo, assegurando o acesso a um local com a tarefa de desbastar vegetação densa) ou para a facilitar (por exemplo, prestando informação sobre a toponímia de um sítio).

De forma elucidativa, o Código de processo Civil espanhol (Ley de Enjuiciamiento Civil) denomina este sujeito que dá apoio técnico na inspeção como "persona técnica o prática en la materia” (art. 353.2, I)" .

A leitura da Exposição de Motivos da Proposta de Lei n..$^{\circ}$ 113/XII (Projecto do Código Processo Civil de 2013) contribuiu para clarificar os propósitos da consagração da nova medida instrutória. Naquela afirma-se que este expediente probatório permite "que sejam averiguados com acrescida eficácia e fiabilidade factos que - não implicando o juízo científico que subjaz à prova pericial - possam ser melhor fixados ou esclarecidos por entidade isenta e imparcial e tecnicamente apetrechada (evitando o habitual recurso à falível prova testemunhal para a sua determinação e dispensando inspecções judiciais que não sejam proporcionais ao relevo e natureza da matéria litigiosa”. Desta fundamentação infere-se que o critério, para dispensar a inspeção judicial e optar pela verificação não judicial, assenta na simplicidade da perceção dos factos. Isto é, se a atestação ou perceção é simples, considera-se desproporcionada inspeção judicial.

Na anotação ao preceito, Ramos de Faria/Ana Luísa Loureiro referem, como exemplo, o caso em que o autor alega que a estrada era, e é, de terra batida, enquanto o réu alega que é asfaltada, podendo o juiz incumbir um oficial de justiça de verificar o facto munido de uma máquina fotográfica ${ }^{12}$. Não sei se será este o melhor exemplo. A nossa lei processual já dispõe de outros meios expeditos para registar tal facto. À luz do art. 437. ․ do CPC (diretriz legal oriunda do artigo 555. do CPC de 1939), o tribunal pode requisitar todo o tipo de documentos, tais como fotografias, plantas, desenhos.

Vejamos um caso que nos foi relatado que lança dúvidas tanto sobre o real campo de acção deste mecanismo, como sobre a correcção da sua localização sistemática.

8 Emilio Betti (Diritto Processuale Civile Italiano, 11.ำ ed, Roma, 1936, p. 432) afirmou que o tempo gasto na inspeção, o valor da imediação (que é "sempre uma garantia de justiça”) e a utilidade da medida probatória deviam fundamentar o juízo de oportunidade de uma inspeção judicial.

9 No ordenamento alemão não há previsão legal expressa sobre a possibilidade de o juiz incumbir outra pessoa de fazer a diligência, mas esta é admitida, a título excecional, sempre que a sua execução não seja exigível ao juiz devido a especiais dificuldades práticas, perigosidade ou pelo facto de envolver a apreciação da intimidade da pessoa. (cf., RosENBERG / Schawb/GotTwald, Zivilprozessrecht, 17. ed, Verlag C.H, Beck, p. 671).

10 No sistema italiano (ainda antes de a figura da perícia ser abarcada no instituto da "consulenza técnica” pela lei processual civil de 1942), Francesco Carnelutti referiu-se ao perito percipiente como aquele que colabora com o juiz na perceção de factos em situações de perigosidade ou para prevenir potenciais adversidades da atividade de inspeção (cf. Sistema di Diritto Processuale Civile, I, Padova, Cedam, pp. 529 e 530).

11 No sistema espanhol, a iniciativa de requerer a realização da inspeção judicial recai sobre as partes, assim como a indicação da pessoa que presta apoio técnico. Veronica López Yagües (La prova del reconocimiento judicial en el proceso civil, La Ley, 1. ${ }^{-}$ed, 2005, p. 191) adverte que a identificação destas pessoas não é tarefa fácil, dizendo que se trata de terceiros, alheios ao litígio, que constituem uma figura incerta, entre a testemunha e o perito, prestando esclarecimento sempre que o juiz os solicite em razão do conhecimento especializado da matéria objeto da diligência.

12 Cf. Ramos de Faria/Ana Luísa Loureiro, Primeiras Notas ao Novo Código de Processo Civil, Vol. I, 2. e ed., Almedina, artigo 494. ${ }^{\circ}$, anotação 1.2 . 
No âmbito de uma ação de reconhecimento de servidão de águas, as partes requereram uma inspeção judicial ao local. O juiz proferiu despacho, determinando a verificação não judicial qualificada. Sustentou que a matéria exigia capacidades técnicas de que o tribunal não dispunha, sendo eventualmente necessário fazer escavações. Determinou que a secção (do tribunal) indicasse pessoa qualificada para a prática desta inspeção, podendo acompanhar-se de auxiliares com vista à escavação. Identificaramse os vários objectivos: verificar se determinados prédios estavam ou não cultivados, averiguar quais as águas existentes nos prédios x e y, se existem canos de pedra ou tubos em pvc, se a água corria ou não à superfície, etc. Quem é este técnico ou pessoal qualificado que vai "inspeccionar" o local? Que enquadramento processual merecerá?

Perante os fins deste expediente probatório e atendendo às especificidades técnicas da situação controvertida, quer-nos parecer inadequada uma verificação não judicial qualificada. Ao caso, ao invés do decidido, ajustar-se-ia a realização de uma perícia ${ }^{13}$.

\section{O técnico ou pessoal qualificado no contexto do novo meio de prova}

A figura do técnico não é uma novidade na legislação processual portuguesa. Nas sucessivas reformas permaneceram intocados os preceitos que prevêem a possibilidade de, na inspeção judicial, ojuiz se fazer acompanhar "de pessoa que tenha competência para o elucidar sobre a averiguação e interpretação dos factos que se propõe observar" (actual artigo 492.․, cuja epígrafe é "Intervenção de técnico”)14. Também se continua a admitir a intervenção de um técnico, por iniciativa oficiosa, na audiência final quando a matéria de facto suscite "dificuldades de natureza técnica cuja solução dependa de conhecimentos especiais que o tribunal não possua” (cfr. artigo 601.o). Estes técnicos assumirão, por conseguinte, uma função meramente auxiliar da atividade judicial. O Acórdão da Relação do Porto, de 8/11/201215, identifica correctamente a sua função quando afirma que esta “(...) intervenção de técnicos no processo não constitui meio de prova, mas apenas meio de habilitar o juiz com o grau de compreensão da realidade sob julgamento que lhe permita compreendê-la suficientemente para a apreender de modo correcto e poder julgá-la capazmente".

Somos de opinião que o sujeito que efectua a verificação não judicial não é (ou não deve ser) diferente deste "técnico" ao qual se referem os artigos 492. e 601.⒗ Note-se, porém, que tal não significa que assuma no processo as mesmas funções, mas apenas que deve sujeitar-se a algumas regras comuns.

Em suma, nesta visão global do sistema processual, o técnico, que colabora com a justiça, pode "multiplicar-se" em múltiplas atividades, de cariz mais ou menos complexo. Pode ser um mero auxiliar do juiz, contribuindo para a melhor compreensão e valoração da prova e seus resultados; outrossim pode ser o agente da própria prova - como sucede no contexto do novo artigo 494.‥ Ou seja, não propugnamos pela autonomização conceitual da figura do técnico (que executa tarefas que o juiz lhe atribui à luz do artigo 494.o ) sob pena de a lei processual revelar falta de unidade e coerência.

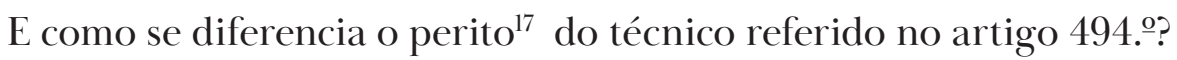

13 Ao analisar esta figura em confronto com o perito (alicerçada na redação do artigo 388.ำ do Código Civil), IsaBEL Alexandre conclui que "as verificações não judiciais não se distinguem da prova pericial em atenção às características da pessoa que as realiza” («A fase da instrução e os novos meios de prova no Código de Processo Civil de 2013», Revista do Ministério Público, 134: Abril/Junho 2013, pp. 9 e ss, sobretudo p.39).

14 Os advogados também podem assessorar-se de técnicos nos termos do artigo 50.ํ do CPC.

15 Processo 6439/07.3TBMTS.P1, in www.dgsi.pt..

16 Cf., em sentido contrário, Isabel Alexandre, afirmando que o técnico a que se reporta o artigo $492 .{ }^{\circ}$ não se confunde com o técnico ou pessoa qualificada que intervém na inspeção judicial (cf. «A fase da instrução e os novos meios de prova no Código de Processo Civil de 2013», p. 38).

17 Cf. artigo 388..$^{\circ}$ do Código Civil. No sistema processual civil do Brasil, a perícia pode revestir a modalidade de judicial (com elaboração de laudo ou com dispensa de laudo) ou extrajudicial (pareceres técnicos juntos pelas partes). Vide, sobre estas modalidades, Luiz Rodrigues Wambier/Eduardo Talamini, Curso Avançado de Processo Civil, volume 2, cit., expressamente pp. 349 e 350. 
Como já tivemos ocasião de sublinhar noutro estudo ${ }^{18}$, o nosso modelo processual parece assentar no tratamento do perito e do técnico como figuras distintas e autónomas. Esta duplicação de sujeitos (com dimensão técnica) é uma "originalidade" do sistema português, que não se afigura muito razoável nem encontra paralelo em ordenamentos europeus mais próximos.

Numa compreensão unitária do regime processual, dir-se-á que o perito é um técnico, mas nem toda a intervenção de um técnico no processo se reconduz a uma perícia. Assim, por exemplo, um médico ${ }^{19}$ pode ser designado como perito, submetendo-se a sua intervenção processual a um procedimento probatório tipificado na lei ${ }^{20}$, ou poderá apenas ser requisitado para participar como mero "assessor técnico" do juiz no momento da audiência final (artigo 601. ${ }^{\circ}$ ) ou até para elaborar um parecer (artigo $436 .^{\circ}$ do $\left.\mathrm{CPC}\right)^{21}$.

É de elogiar a solução italiana que reconduziu todo e qualquer apoio técnico à figura da "consulenza tecnica" (abarcando o perito nesta figura, por conseguinte) ${ }^{22}$. O "consulente técnico", nomeado oficiosamente, tem uma função auxiliar e integrativa ${ }^{23}$ da atividade judicial do tribunal, prestando a sua colaboração sempre que sejam necessários conhecimentos técnicos ou científicos mais ou menos especializados. Constitui um "meio de indagação" destinado a iluminar o juiz em determinadas áreas não jurídicas ${ }^{24}$.

Nesta incursão pelo direito comparado, revela-se também cativante o regime francês, embora sem a flexibilidade e abrangência da figura da intervenção técnica do sistema italiano. Por um lado, concebeuse um corpo de normas comuns a todas as medidas instrutórias executadas por um técnico, por outro lado, no art. 232 Code de Procédure Civile ${ }^{25}$ decompôs-se a intervenção técnica em três modalidades: a "constatation", a "consultation" e, reservada a casos mais complicados, a "expertise", consagrando-se regras especificas para cada uma delas. Enquanto a primeira envolve uma mera "constatação" feita por um técnico (que se tem entendido que pode ser um huissier de justice $e^{26}$ ), sem envolver qualquer opinião,

18 Entendimento desenvolvido no nosso estudo: «A enigmática figura do técnico no Código de Processo Civil» Estudos de Homenagem ao Prof. Doutor Lebre de Freitas. Coimbra: Coimbra Editora, 2013, pp.1045 a 1067.

19 Outra questão é a de saber se, por exemplo, um médico que tenha presenciado um qualquer acidente de trânsito pode ser testemunha e (também) perito. É evidente que o relato (do que se passou) será sempre coado pelos olhos de quem é entendido na matéria, embora seja casual e insubstituível (diversamente da perícia que tem de ser requerida e pode ser realizada por quem tenha competência para tal). Contudo, o nosso sistema não admite expressamente a figura da testemunha-perito, como o fazem os ordenamentos alemão (\$ 414 ZPO) e espanhol (art. 370. 4 LEC). À luz da lei portuguesa, o exercício da função de perito pressupõe determinadas garantias de imparcialidade, o que dificulta a admissibilidade de uma testemunha pericial. Neste enquadramento, o Acórdão da Relação do Porto, de 12-05-2005 (Processo n.o 0532019) fundamentou-se no facto de os impedimentos aplicáveis aos peritos serem equivalentes aos dos juízes (o atual artigo $470 . \stackrel{\circ}{\circ}$ do CPC) para concluir que não podem coincidir no mesmo sujeito as qualidades de perito e de testemunha [cf. artigo 115.. , n. ${ }^{\circ}$, al. h) ]. Em conformidade, convidou a parte interessada a esclarecer a modalidade de intervenção processual do sujeito em causa. Todavia, sem pôr em causa a correção da fundamentação do Acórdão, apraz-nos notar que a impossibilidade desta "dupla categoria”, relativamente à mesma pessoa, pode, em alguns casos, enfraquecer o apuramento da verdade (na hipótese, imagine-se, de ter sido o médico a única pessoa que presenciou o acidente).

20 Cf. artigos 467.. a $489 . .^{\circ}$ do CPC. Igualmente ficam sujeitos ao regime jurídico das perícias médico-legais e forenses

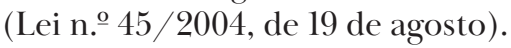

21 Anote-se que estes pareceres não seguem qualquer rito legal, apresentando-se sob a forma documental, para valerem como meras opiniões dadas por especialistas, sobre questões de natureza técnica não jurídica. Vide, problematizando o enquadramento dogmático e defendendo o seu relevo como princípio de prova, o nosso estudo, «A enigmática figura do técnico no Código de Processo Civil», cit., pp. 1061 a 1065.

22 Cf. Francesco P. Luiso, Diritto Processuale Civile, II (Processo di Cognizione), 4. a ed, Giuffrè Editora, pp. 92 a 94.

23 Cf. Nicola Picardi, Manuale del Processo Civile, 3. ${ }^{a}$ ed., Giuffrè Editora, p.342.

24 Cf. Luigi Paolo Comoglio, La prova civile, Utet, 2010, p. 854. No acompanhamento desta atividade, as partes podem ter a assistência de um técnico (consulente di parte).

25 Art. 232 : «Le juge peut commettre toute personne de son choix pour l'éclairer par des constatations, par une consultation ou par une expertise sur une question de fait qui requiert les lumières d'un technicien ».

26 Vide, comentando favoravelmente uma decisão da Cour de Cassation (de 23 de junho de 2011) que aprovou a designação de um huissier de justice para “constatações” puramente materiais, Natalie Fricero, «L'huissier de justiceconstatant au sens de l'article 249 du Code de procédure civile est né!», Semaine juridique, I, № 36, 2011 , págs. 1545 -1547. 
a consulta já envolve a solicitação de um parecer $^{27}$. A perícia, propriamente dita, está reservada àqueles casos mais complexos, acarretando inevitavelmente mais custos ${ }^{28}$.

Neste enquadramento conceitual, a verificação não judicial qualificada terá semelhanças com a figura da "constatation" ". A propósito desta modalidade, Jacques Héron/Thierry Le Bars assinalam que "o atestador (constatant) é encarregado de ver no lugar do juiz" ${ }^{30}$. Ficam abarcados, por conseguinte, aqueles casos em que um técnico/pessoa qualificada assume a incumbência de verificar ("constatar") situações factuais, mas cujo grau de complexidade não ascende à de uma perícia. Por outro lado, com o recurso à figura de um "técnico ou pessoa qualificada" ultrapassa-se a fragilidade da prova testemunhal, pois a credibilidade do relato deste sujeito será, provavelmente, maior.

De qualquer modo, talvez fosse necessário repensar o nosso ordenamento jurídico processual de modo a uniformizar e abranger num único instituto as várias modalidades de intervenção de um sujeito com conhecimentos em áreas do saber não jurídico, sem prejuízo da salvaguarda de algumas diferenças de regime (atendendo às particularidades de cada modalidade/espécie).

Quanto a custas judiciais, a verificação não judicial deve distanciar-se da perícia. Parece lógico e sensato que os custos desta atividade instrutória não sejam equivalentes àqueles que geram as perícias, atendendo à graduação de "esforços". A atividade de constatação não pressuporá a complexidade de uma perícia nem exigirá tantos conhecimentos específicos.

Contudo, não está isenta de dúvidas a distribuição dos encargos na hipótese de apenas uma das partes ter requerido a inspeção judicial, tendo esta sido "convolada" ex officio para verificação não judicial atendendo à natureza da matéria. Quem os suporta? O artigo 532.. do CPC prescreve que os encargos são da responsabilidade da parte que requereu a diligência e, no caso de ter sido realizada oficiosamente, suportá-los-á a parte a quem aproveita a diligência. Cremos que, neste caso, será mais razoável aplicar o regime relativo à hipótese de a diligência ter sido decretada oficiosamente. Neste enquadramento, se ambas tiverem interesse ou igual proveito da diligência (assim como em caso de dúvida), os encargos serão repartidos de modo igual entre as partes (cfr. n. 9 do artigo 532.․ do CPC).

Num ponto específico, o técnico aproximar-se-á do perito: a sua atividade deve pautar-se por equivalentes garantias de imparcialidade e de independência. Ou seja, os impedimentos e suspeições, aplicáveis aos peritos (cf. artigo 470. do CPC) devem ser aplicáveis ao técnico, salvo se a "pessoa qualificada"31, designada para a atividade probatória, beneficiar de um regime especifico inerente à sua profissão (no caso de ser agente de execução ou funcionário da secretária do tribunal) ${ }^{32}$.

\section{Atestações realizadas por autoridade ou oficial público}

27 Jacques Héron/Thierry Le Bars apelidam a "consultation" de "mini-expertise" e esclarecem que a constatation exclui toda e qualquer explicação por parte do técnico (cf. Droit Judiciaire Privé, 3.․ ed., Montchrestien, pp.865 e 866).

28 Serge Guinchard / Frédérique Ferrand sublinham que a "decomposição" da perícia tradicional em três modalidades acautela perda de tempo e de custos (cf. Procédure Civile-Droit interne et droit communautaire, 28. e. ed., Dalloz, pp. 967 e ss, especialmente pp. 967 e 968$)$.

29 Rui Pinto refere-se à verificação não judicial qualificada como "constatação ou atestação judicialmente provocada" (cf.ob.cit., artigo 494.․ p. 399). Confronta-a com o "constat" do regime francês (auto elaborado pelo huissier de justice) e com figura da ata notarial no Brasil, explicitando que estes "são atos de atestação autónoma, não processuais, pois são exarados por entidade com poderes públicos, gozam de fé pública e não carecem de estar inseridos num procedimento judicial” ( $o b$. cit., p. 398).

$30 \quad$ Cf. ob.cit, p. 865.

31 Cf., assinalando as categorias diversas de pessoas com qualidade pública ou técnica para a verificação não judicial, Rui Pinto, Notas ao Código de Processo Civil, Coimbra Editora, 2. ${ }^{a}$ ed., 2015, pp. 399 e 400. No mesmo sentido, Paulo Pimenta sublinha que o grau de qualificação dependerá sempre do que estiver em causa, sendo possível que tal tarefa seja atribuída a um funcionário judicial, a um agente de execução ou até a um notário (cf.ob.cit, p. 363). No contexto francês, a propósito da figura da constatation, Jacques Héron/Thierry Le Bars referem que o recurso a uma pessoa de confiança do juiz, seja ele ou não um huissier de justice, não pressupõe que ele seja um técnico no sentido corrente do termo, pois é antes a experiência que faz dele um «especialista de constatações» (ob.cit., p. 865).

Cf., por exemplo, artigo 118. o do CPC. 
No n. 2 do artigo 494. . faz-se referência às atestações realizadas por autoridade ou oficial público ${ }^{33}$. Relativamente à identidade da "autoridade ou oficial público", questiona-se ${ }^{34}$ se um notário pode efectuar uma verificação não judicial. A Ordem dos Notários, no Parecer sobre o Projecto de Código de Processo Civil ${ }^{35}$, propôs que ficasse expressamente especificado que o notário podia ser incumbido "quando atentas as suas especiais competências em matéria de verificação e autenticação de factos e documentos tal se mostre adequado (...)”. Esta menção não ficou, porém, a constar da versão final, permanecendo, no nosso ponto de vista, as reticências sobre a viabilidade de uma "atestação notarial" por ordem do juiz.

Assinale-se o facto de art. $384^{36}$ do Código de Processo Civil do Brasil ter expressamente previsto a possibilidade da "ata notarial" ser utilizada como prova num processo judicial ${ }^{37}$. Contudo, não surge nas vestes de "prova constituenda" (característica da verificação não judicial qualificada), mas sim revelase como prova pré-constituída. Trata-se, por conseguinte, de um instrumento lavrado pelo tabelião, a requerimento de pessoa interessado, que se destina a atestar e documentar a existência de facto, sendo sobretudo considerado relevante como representação documental do conteúdo de páginas eletrónicas e de outros documentos elaborados nas novas tecnologias de informação e comunicação ${ }^{38}$. Consubstancia uma "maneira peculiar de criação de documento público, cuja finalidade é, especificamente, servir de "meio de prova" 39 .

Tal figura merecerá maior reflexão (o que extravasa o objeto do presente estudo), pelo que, de momento, só assinalamos que a circunstância de a "constituição" desde documento dispensar a presença do sujeito contra quem vai ser utilizado, suscita-nos o receio de que o exercício do contraditório (diferido para a futura ação) saía fragilizado ${ }^{40}$, sobretudo naqueles casos em que tal "criação" já ocorra num ambiente "litigioso" entre as potenciais partes (mas ainda antes de ser intentada uma causa).

\section{A reconstituição de factos}

Retornando à figura das verificações não judiciais qualificadas, recordemos que estas são suscetíveis de ter como objecto não apenas a "inspeção" de coisas ou lugares, mas também a "reconstituição de factos". Esta perceção (por terceiro que não o juiz) da atividade de reconstituição de situações passadas, parecenos problemática, justificando, no nosso parecer, uma interpretação restritiva do âmbito de aplicação do expediente probatório.

33 Vide, assinalando que, no caso de a verificação não judicial ser emitida por autoridade ou oficial público, estamos perante prova documental, Lebre de Freitas, A ação declarativa comum à luz do Código de Processo Civil de 2013, 4. ed., Gestlegal, 2017 , p.347.

34 Cf. Isabel Alexandre, «A fase da instrução e os novos meios de prova no Código de Processo Civil de 2013», cit., p. 41.

35 Parecer da Ordem dos Notários, in http://www.parlamento.pt/AtividadeParlamentar/Paginas/DetalheIniciativa. aspx?BID=37372

36 Este preceito determina que: “[A] existência e o modo de existir de algum fato podem ser atestados ou documentados, a requerimento do interessado, mediante ata lavrada por tabelião", e o $§$ único acrescenta que que "Dados representados por imagem ou som gravados em arquivos eletrónicos poderão constar da ata notarial”.

37 Vide, as nossas apreciações críticas sobre esta figura, «Principais Novidades sobre Provas no Novo Código de Processo Civil Português», in Processo Civil Comparado: Análise entre Brasil e Portugal, São Paulo: Forense, 2017, sobretudo pp. 203 a 206.

38 Cf. Luiz Guilherme MARINONi/SÉrgio Cruz ARENHART, Prova e Convicção: de acordo com o CPC de 2015, 3. a ed., São Paulo: Revista dos Tribunais, 2015, p. 429. À luz do regime português, Lú́s Filipe Pires de Sousa (Direito Probatório Material Comentado, Almedina, 2020, p. 197) admite, como modalidade da inspeção judicial, a "cibernavegação", «(...) no âmbito da qual a parte faculta ao juiz um computador, ou este utiliza um próprio, com acesso à internet, a fim de o juiz se inteirar, diretamente e na presença das partes, do conteúdo de sites ou de correio eletrónico trocado entre as partes».

39 Cf. MARINONI/ARENHART, ob.cit., p. 430.

40 Fredie Didier JR/Rafael Alexandria de Oliveira / Paula Sarno Braga (Curso de Direito Processual Civil, Vol. 2, 12. ed., Editora JusPODIVM, pp. 240 e 241) chamam a atenção para algumas "fragilidades" da figura, não obstante a fé pública do tabelião. Referem, por exemplo, o facto de a ata notarial ser produzida unilateralmente sem a participação da parte contra quem se apresentará (num futuro processo) e a eventualidade de o tabelião não ter o conhecimento técnico para registar o estado de conservação de um imóvel. Concluem, afirmando que nada afasta "a necessidade de o juiz dar-lhe o valor que, no caso concreto, ela merece, inclusive repetindo a diligência outrora efetivada pelo tabelião (...)”. 
A partir do Código de Processo Civil de 1961, a inspeção judicial estendeu o seu campo de acção às coisas móveis e às pessoas, mas também se admitiu, por inspiração da lei italiana, a reconstituição de factos sempre que o juiz a considerasse necessária ${ }^{41}$. Enquanto a primeira tem por objeto a perceção estática de coisas, lugares ou pessoas nas condições actuais, a segunda implica a reconstrução dinâmica, mediante recurso a aplicação empírica de métodos experimentais, de um facto histórico pertencente ao passado ${ }^{42}$. Embora esta "simulação" seja mais comum no âmbito do crime ${ }^{43}$, não será invulgar uma atividade reconstitutiva para apreender, por exemplo, a dinâmica de um acidente de trânsito.

Entendemos que esta "encenação" deve ser presenciada (e dirigida activamente) pelo juiz e não por um terceiro, por mais qualificado que seja. Neste contexto, os técnicos, a serem requisitados, terão uma função meramente auxiliar, sob pena, desde logo, de se frustrar a sua real potencialidade probatória, qual seja a de o juiz poder adquirir, por perceção directa, os correctos dados resultantes do entrecruzamento das dinâmicas temporal e espacial do caso.

Um outro aspecto contribui para manifestarmos as nossas hesitações quanto à admissibilidade de uma reconstituição de factos "presidida" por uma pessoa, que é qualificada, mas não é o juiz da causa. Tal sucede quando reconduzimos este especial mecanismo, na senda de Francesco Luiso, à categoria de prova presuntiva ${ }^{44}$. Na reconstituição de factos, explicita Luiso, "o juiz não entra em contacto com o facto histórico relevante, mas com a reprodução desse facto, e com base nas regras da experiência, deduz, da forma como o facto se verificou durante a reconstituição, o modo como ocorreu o facto histórico relevante" ${ }^{45}$. A reprodução histórica consubstanciará a base de presunções judiciais, ou seja funcionará como um método probatório. As ilações têm de emanar do juiz ${ }^{46}$ e irão constar da fundamentação da sentença (n.․ 4 do artigo 607. do CPC). A sua correção e pertinência dependerá da "imediação" que for respeitada nessa atividade probatória. Ou seja, da presença do juiz e não de qualquer intermediário.

Ressalve-se que, como adverte Comoglio, a reconstituição pode aproximar-se da prova científica ${ }^{47}$ (por pressupor conhecimentos técnicos ou científicos específicos no apuramento da causa-efeito/ análise de probabilidades). Neste circunstancialismo, a diligência sairá da esfera da inspeção judicial e entrará no campo das perícias.

\section{A produção antecipada de uma verificação não judicial qualificada}

Em caso de fundado receio de a prova se tornar impossível ou muito difícil de obter no momento em que é normalmente produzida, o artigo 419. admite a sua antecipação. Este preceito refere-se ao "depoimento", à "perícia" e à "inspeção" como possíveis provas antecipadas, tendo permanecido inalterada a redação na Reforma de 2013. Contudo, a omissão da referência ao novo meio de prova não ditará inelutavelmente uma resposta negativa ${ }^{48}$. Em termos sistemáticos, a actual lei corrobora a recondução da verificação não judicial ao mesmo "plano percetivo" do que a inspeção, como em termos conceituais e de regime probatório, a verificação não judicial se aproxima da perícia (conforme temos vindo a assinalar). Logo, preenchidos os pressupostos de uma antecipação de uma atividade de simples perceção de factos materiais, simples e de cariz objetivo, nada parece obstar a sua imputação a um técnico ou pessoa qualificada para tal.

\footnotetext{
41 Conforme nos é relatado por Antunes Varela/M. Bezerra/Sampaio Nora, ob.cit., p. 604.

42 Cf. Comoglio, ob.cit., p. 838.

$43 \mathrm{O}$ art. 150. do Código de Processo Penal prevê a "reconstituição do facto" como meio de prova, regulando os seus pressupostos e procedimento.
}

44 Cf., neste sentido, Rosaria Giordano, L'istruzione probatoria nel processo civile, Giuffrè Editora, 2013 , p. 299.

45 Francesco Luiso, ob.cit., p. 160.

46 Cf. artigo 349..$^{\circ}$ do CC.

47 Comoglio assinala a estreita relação da reconstituição com a prova científica, pois a reconstituição só será útil se a prior for tecnicamente possível reproduzir experimentalmente o facto nas mesmas situações e condições em que se afirma ter-se verificado (cf. ob.cit., p. 838).

48 Cf., revelando dúvidas sobre a admissibilidade de uma verificação não judicial antecipada, RAMOs DE FARIA/ANA Luísa Loureiro, Primeiras Notas ao Novo Código de Processo Civil, cit., artigo 494., anotação 1.4. 


\section{O relatório do técnico ou da pessoa qualificada: que contraditório?}

O n. 1 do artigo 494.. refere que o técnico ou pessoa qualificada fica incumbido de apresentar relatório ${ }^{49}$, tal como a lei exige ao perito ${ }^{50}$. O n. 2 do mesmo preceito só ressalva o caso de o acto de "atestação" ter emanado de autoridade ou oficial público. Nesta hipótese revestirá a natureza de documento autêntico (cf. artigo 371. - do CC).

Tal como numa inspeção judicial, no cumprimento da audiência contraditória ${ }^{51}$, as partes (e seus advogados) são notificados da hora e local da diligência. Neste acompanhamento da prova, as observações das partes terão de circunscrever ao objecto da verificação não judicial pré-determinado pelo juiz (embora após audição das partes).

O relatório do técnico ou pessoa revelará sempre a "perspetiva" dos factos percecionados por um terceiro, não obstante a objetividade e a simplicidade da matéria "constatada". Por isso, entendemos que talvez se justifique que seja conferida às partes a prerrogativa de reclamar do relatório em caso de deficiência, obscuridade ou contradição (aplicando-se analogicamente n.o 2 do artigo 485. o do CPC).

Perante o avanço tecnológico dos nossos dias, o sujeito designado deverá poder servir-se de todos os meios adequados ao registo (de som ou imagem) da sua atividade (e não apenas de fotografias, como está previsto para a inspeção judicial no artigo 493. do $\mathrm{CPC}^{52}$ ). Este registo poderá ser útil tanto na valoração probatória como na hipótese de reapreciação da matéria de facto por instância superior.

No entanto, os pressupostos de uma segunda verificação não judicial qualificada dificilmente ocorrerão devido à pouca complexidade da matéria factual em causa (diferentemente do que pode suceder quando estiver em causa uma perícia - artigo 487. do CPC).

E o relatório terá necessariamente de ser escrito ${ }^{53}$ ? O "velho" princípio da liberdade de forma ${ }^{54}$ tem actualmente de conviver com novos poderes do juiz, nomeadamente o da adequação formal (artigo 547. ․ do CPC). Este apela tanto à flexibilização dos requisitos atinentes à regularidade formal dos actos processuais como do seu conteúdo. Logo, entendemos que o tribunal tem a faculdade de, perante a natureza da matéria "constatada", dispensar a apresentação de relatório escrito, bastando-se com a prestação de esclarecimentos orais na audiência final.

\section{A eficácia extraprocessual da verificação não judicial qualificada}

Nos termos do artigo 422.. do CPC, o princípio do valor extraprocessual das provas permite que os depoimentos e perícias possam ser utilizados contra a mesma pessoa num outro processo. Entendemos que o relatório emergente de uma verificação não judicial não deve ficar excluído deste valor. Tal aproveitamento pressupõe que a atividade probatória, do primeiro processo, não ofereça garantias inferiores às do segundo, tendo ocorrido ao abrigo do princípio da audiência contraditória. Essencial é que tudo se passe como se a prova fosse produzida neste "segundo" processo. No caso de a atestação constar de documento emanado de oficial público, não se coloca esta questão, uma vez que " através de certidão, cópia, fotocópia ou desentranhamento do documentos dos autos, a parte interessada pode facilmente obter a junção da prova ao novo processo" ${ }^{55}$.

49 Em sentido divergente, pronuncia-se Rui Pinto (ob.cit., p.402), entendendo que o relatório consubstancia um documento escrito.

$50 \quad$ Artigo $484 .^{\circ}$ do CPC.

51 Cf. artigo 415.

52 A Ley de Enjuiciamiento Civil, no seu art. 359, autoriza o emprego de meios técnicos de gravação de imagem ou de som do ato de inspeção judicial.

53 Cf., respondendo negativamente, Isabel Alexandre, «A fase da instrução e os novos meios de prova no Código de Processo Civil de 2013», cit., p. 40.

54 Que se manteve inalterado no artigo 131. do CPC.

55 Cf.Antunes Varela/M.Bezerra/Sampaio Nora, ob.cit., p. 492. 
Ao invés, a inspeção judicial ${ }^{56}$ é preterida do âmbito do referido preceito ${ }^{57}$, porquanto as perceções, interpretações ou deduções do juiz (que o persuadem de uma determinada realidade) são subjetivas e pessoais. Nem o facto de se lavrar auto da inspeção, afasta esta "particularização". A propósito do valor do auto da inspeção, são pertinentes as observações constantes do Acórdão da Relação de Coimbra, de 14/10/2014, supra referenciado: "o auto não é fundamento da convicção, embora, claro, possa cumprir o papel de auxiliar de memória daquilo que foi percepcionado no acto; a convicção do juiz forma-se com o acto - e não com o auto". Este auto será como o "retrato" escrito do que se passou. Conterá elementos, uns de natureza objetiva (o lugar, hora da diligência, identificação dos presentes e do objeto inspecionado), outros de cariz subjetivo (apreciações feitas por todos os intervenientes) ${ }^{58}$. Nestes pressupostos, o valor probatório do auto distingue-se da diligência propriamente dita ${ }^{59}$. O auto, como documento autêntico, prova plenamente que, em determinado dia, foi feita tal diligência e que se atestaram/percecionaram tais e tais factos. No que diz respeito às apreciações do juiz, o seu caráter pessoal compromete que a inspeção judicial possa ser "emprestada". Esta sua natureza de prova direta - em que a fonte da convicção do juiz é a própria diligência e não o seu relato - constitui um obstáculo ao seu aproveitamento noutro processo.

Quando as verificações não judiciais qualificadas são efectuadas por sujeito que não é oficial público, o conteúdo das "perceções" consta, em regra, de um relatório (escrito), o qual não merece o tratamento (processual) de um "auto de inspeção judicial”. Servirá, em conjunto com as demais provas, para formar uma prudente convicção tanto do juiz da causa como de um outro que julgue, noutro processo, a certeza positiva ou negativa de factos semelhantes. Nestes termos, poderão valer fora do processo onde foram produzidas, sob a égide da livre (mas fundamentada) apreciação.

\section{O "lugar" das verificações não judiciais qualificadas no processo civil português: notas conclusivas.}

A previsão de novas figuras deve ter como objetivo a sanação das fragilidades da arquitectura processual, sob pena de contender com o espaço reservado a outros institutos. O novo meio de prova surgiu descarnado. Merecia um corpo de normas que lhe conferissem identidade própria. Assim, vagueia entre o campo de acção de uma inspeção judicial e a intervenção técnica, sem amarras seguras e sólidas.

Os contornos imprecisos do sujeito competente - técnico ou pessoa qualificada - são dignos de crítica.

A referência à figura do "técnico", com funções de mera "atestação" de factos, leva a questionar a unidade e coerência do nosso sistema processual no que toca à intervenção de "especialistas" com saber não jurídico numa ação pendente.

Quanto ao regime, não obstante a incompletude do sistema legal, justifica-se que a verificação não judicial se aproxime da prova pericial, embora preserve alguma individualidade, tendo em conta o seu âmbito de aplicação.

De qualquer modo, somos de opinião que o recurso à verificação não judicial qualificada, em desfavor de uma perceção direta dos factos pelo tribunal, não pode ser discricionário. Os valores da imediação, essenciais na formação directa, segura e fundada da convicção do juiz, apenas podem ser preteridos quando ocorram indícios claros da objectividade e da simplicidade da matéria que constitua objecto da prova. Somente nestes pressupostos, será razoável, depois de ouvir as partes, determinar a realização de uma verificação não judicial qualificada.

56 Antunes Varela/M. Bezerra/Sampaio Nora, ob.cit., pp. 492 e 493.

57 Cf. artigo 421..$^{\circ}$ do CPC.

58 A doutrina espanhola distingue na ata de "reconhecimento judicial" os dados subjetivos daqueles objetivos (cf., por todos, Juan Montero Aroca/J.L. Gómez Colomer/S.Barona Vilar/ M.P. Calderón Cuadrado, Derecho Jurisdiccional II (Proceso Civil), 21. ㄹ ed, Tirant Lo Blanch, p. 287).

59 Cf., fazendo esta distinção, Artur Costa/Jaime de Lemos, Processo Comum de Declaração (segundo as prelecções do Prof. Dr. Paulo Cunha ao Curso de Processo Civil, ano lectivo 1939-40), Tomo II, pp.201 e 202. 